\title{
Anaphylaxis due to sulfite intolerance: a protective effect from cyanocobalamin
}

\author{
PM Ojeda, I Ojeda*', G Rubio \\ From Food Allergy and Anaphylaxis Meeting (FAAM 2013) \\ Nice, France. 7-9 February 2013
}

\section{Background}

The mechanisms of sulfite intolerance are unknown. It has been suggested that, in some cases, it could be due to a partial sulfite-oxidase deficiency. In these patients, this enzyme is unable to metabolize adequately an overload of ingested or inhaled exogenous sulfite, triggering a bronchospasm. Cyanocobalamin is able to catalyze the extracellular oxidation of sulfites, preventing sulfite accumulation and the subsequent symptoms due to this excess.

\section{Methods}

A 36 y.o. woman was attended at our allergy Clinic after suffering repeated anaphylactic episodes and an anaphylactic shock, 60 minutes after eating different foods. The allergic study confirmed sensitization to pollens, animal dander, dust mites, molds and PR-10 proteins (ImmunoCAP Isac, Thermofisher, Sweden). We performed a double-blind placebo controlled challenge (DBPCC) with sulfites. She reacted with $50 \mathrm{mg}$ of metabisulfite with facial flushing, rhinitis and bronchospasm (FEV1 decrease $>20 \%$ ).

We recommended a sulfite avoidance diet, but two months later she came back complaining of great difficulty to avoid sulfite given the ubiquity of this additive in nearly all foods.

We performed another sulfite challenge with cyanocobalamin pretreatment.

\section{Results}

We pre-treated the patient with $4 \mathrm{mcg}$ of cyanocobalamin 1 hour before repeating de sulfite challenge. We increased the sulfite dose every 20 minutes, from $5 \mathrm{mg}$ to $200 \mathrm{mg}$. The challenge test was negative. We recommended the patient to take every day $4 \mathrm{mcg}$ of cyanocobalamin in order to prevent anaphylactic reactions from inadvertent exposure to sulfites and to continue with a sulfite

Allergy, Clínica de Asma y Alergia Dres. Ojeda, Madrid, Spain avoidance diet. Since then, she has been stable, without asthma exacerbation or anaphylactic reactions.

\section{Conclusion}

We describe a case of sulfite intolerance with anaphylactic reactions, in which we have been able to demonstrate a protective effect from cyanocobalamin.

\section{Disclosure of interest}

None declared.

Published: 25 July 2013

\section{References}

1. Simon RA: Sulfite sensitivity. Ann Allergy 1987, 59:100-5.

2. Añibarro $B$, et al: Asthma with sulfite intolerance in children: a blocking study with cyanocobalamin. J Allergy Clin Immunol 1992, 90:103-9.

\section{doi:10.1186/2045-7022-3-S3-P15}

Cite this article as: Ojeda et al:: Anaphylaxis due to sulfite intolerance: a protective effect from cyanocobalamin. Clinical and Translational Allergy 2013 3(Suppl 3):P15.

Submit your next manuscript to BioMed Central and take full advantage of:

- Convenient online submission

- Thorough peer review

- No space constraints or color figure charges

- Immediate publication on acceptance

- Inclusion in PubMed, CAS, Scopus and Google Scholar

- Research which is freely available for redistribution

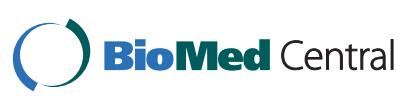

(c) 2013 Ojeda et al; licensee BioMed Central Ltd. This is an Open Access article distributed under the terms of the Creative Commons Attribution License (http://creativecommons.org/licenses/by/2.0), which permits unrestricted use, distribution, and reproduction in any medium, provided the original work is properly cited. 